\section{Agradecimento aOS LeITORES, AUTORES E REVISORES}

\section{ACKNOWLEDGMENT TO READERS, AUTHORS AND REVIEWERS}

\section{Alexandre Prehn Zavascki ${ }^{1,2}$}

Neste fascículo número 4 do volume 35 encerramos nossa atuação como Editor-Chefe da Clinical and Biomedical Research. O trabalho foi iniciado em 2013, com a coeditoria do Prof. Afonso L. Barth, ainda na antiga Revista HCPA. Portanto, coube a este editor a tarefa de transição de nome do periódico. Houve perdas e ganhos, como quase sempre em todas as decisões, e houve erros e acertos ao longo destes três anos à frente da revista. Todo este conjunto de forças, erros e perdas, acertos e ganhos, se equacionarão ao longo do tempo e desejo que com o esforço contínuo da nova equipe editorial, o vetor, ao fim, indique a direção do progresso.

Já agradeci em editoriais anteriores a todas as pessoas da equipe editorial e do Grupo de Pesquisa e Pós-graduação do HCPA que me ajudaram nesse período e, agora, apenas renovo meus agradecimentos. Há, porém, um grupo especial de pessoas que gostaria de direcionar meu agradecimento especial, um grupo pequeno, ainda, mas que certamente, de todos, era o que mais nos motivava para o trabalho. Trata-se dos leitores da revista com quem tive contato, de um pequeno número de pessoas que, nos corredores do hospital, paravam-me, comentavam algum artigo ou dirigiam, espontaneamente, um elogio após a publicação de um novo fascículo. Desejo que estas pessoa saibam que essas simples ações foram sempre um grande incentivo.

Seria impossível a existência da revista sem que os autores enviassem os seus trabalhos a ela. De certa forma, entendo como um gesto, talvez paradoxal, de aposta e de confiança. Agradeço especialmente por apostarem na revista, confiando no seu propósito e seriedade. Esperamos, enquanto equipe editorial, ter retribuído com a publicação de artigos fiéis às expectativas dos autores.

Os tempos são, como nunca, corridos, atribulados. Sabemos o quanto custa o tempo dispendido para ler, analisar e emitir por escrito considerações sobre um manuscrito. $O$ trabalho de revisão por pares é o trabalho mais importante nesta engrenagem e, seguramente, o menos reconhecido academicamente e em nossa cienciometria. Trata-se verdadeiramente de uma doação, notadamente quando estamos nos referindo a periódicos de menor porte como o nosso. Muito obrigado aos revisores pela enorme colaboração!

Por fim, desejo muito sucesso à nova equipe editorial e, mais uma vez, agradeço por ter recebido a oportunidade de colaborar, esperando ter feito o melhor possível.
Clin Biomed Res. 2015;35(4):177

1 Serviço de Infectologia, Hospital de Clínicas de Porto Alegre (HCPA). Porto Alegre, RS, Brasil.

2 Departamento de Medicina Interna, Universidade Federal do Rio Grande do Sul (UFRGS). Porto Alegre, RS, Brasil.

Autor correspondente: Alexandre Prehn Zavascki E-mail: azavascki@hcpa.ufrgs.br Hospital de Clínicas de Porto Alegre (HCPA)

Rua Ramiro Barcelo 2350.

90035-903, Porto Alegre, RS, Brasil. 